Dominika Kossowska

Uniwersytet Warszawski, Warszawa

\title{
Analiza powstawania synkretycznych stylów zdobniczych w Azji Środkowej w VI-VIII w. n.e. na podstawie tkanin z Kotliny Turfańskiej
}

Azja Środkowa w I tysiącleciu n.e. była obszarem bardzo różnorodnym pod względem kulturowym. Było to spowodowane przemieszczaniem się ludności koczowniczej, tworzeniem się silnych konfederacji, a także podbojami ościennych imperiów takich jak Chiny, imperium kuszańskie czy sasanidzkie (224-651 r. n.e.). Duży wpływ na kulturę miał także handel dalekosiężny, rozwijający się na tzw. Jedwabnym Szlaku. W Azji Środkowej doszło do powstania nowej jakości kulturowej, która rozprzestrzeniła się na resztę ówczesnego świata. Bardzo ciekawym przykładem przejmowania i łączenia tradycji są wzory na tkaninach wykonywanych od VI do XII w. n.e., zarówno w warsztatach bizantyjskich, arabskich, jak i chińskich. Materiały zdobiły m.in. motywy antytetycznie ustawionych zwierząt, umieszczonych $\mathrm{w}$ medalionach obramowanych ornamentem pereł (ang. pearl roundel). Wzór ten jest kompilacją motywów zaczerpniętych z sasanidzkiej Persji oraz Chin. Połączenie obu tradycji miało miejsce najprawdopodobniej w Azji Środkowej. Najwcześniejsze przykłady jego użycia pochodzą z oazy Turfan (Wschodni Turkiestan), choć część badaczy za prekursorów nowego stylu uważa mieszkańców Sogdiany. Niniejszy artykuł ma na celu prześledzenie procesu klaro- 
wania się owego synkretycznego stylu w zdobnictwie tkanin na podstawie analizy materiałów z Kotliny Turfańskiej.

Motywami zaczerpniętymi z sasanidzkiej Persji od VII w. n.e. aż do XII-XIII w. n.e. zdobiono luksusowe tekstylia tkane zarówno w warsztatach europejskich, jak i dalekowschodnich. Występowały one nawet w Indiach, Egipcie i Nubii (Compareti 2006: 149). Dziś znane są głównie z prywatnych kolekcji oraz depozytów z europejskich klasztorów (il. 1), dokąd dotarły ze Wschodu wraz z relikwiami świętych (Ghirshman 1962: 227). Moda na tekstylia wzorowane na tkaninach sasanidzkich mogła przybyć do Europy bezpośrednio z Persji. Znacznie bardziej zagadkowe jest występowanie wzorów, które łączyły w sobie zarówno perską, jak i chińską tradycję zdobniczą. Dotyczy to przede wszystkim tkanin zaliczanych do tzw. grupy zandaniji, tekstyliów odkrytych w ostatnich latach na terenie Tybetu (il. 2, 3), a także materiałów chińskiej (il. 4) i japońskiej (il. 5) proweniencji. Podobnie jak w sasanidzkiej Persji, owe materiały tkano z jedwabnych nici splotem wzorzystym wątkowym o wiązaniu skośnym (samit). Jest to splot polegający na przeplataniu nici wątku podstawowego i kolorowych nici wątku dodatkowego z nitką osnowy podstawowej i figurowej. Wzór tworzony jest poprzez dobieranie właściwych nici wątku dodatkowego. Osnowa figurowa wiąże tkaninę w sposób skośny. Początkowo splot wzorzysty wątkowy o wiązaniu skośnym był charakterystyczny jedynie dla ośrodków zachodnich (Syria, Persja, później Sogdiana).

Wzór, któremu jest poświęcona niniejsza praca, ulegał licznym przekształceniom i unowocześnieniom, jednak konwencja wciąż pozostawała ta sama. Pierwotnie składał się z motywów zaczerpniętych ze sztuki sasanidzkiej i chińskiej. Z Persji pochodzą przedstawienia zwierząt. Są to przede wszystkim kaczki, pegazy, bażanty, pawie, gołębie, żurawie, barany, orły, protomy dzików oraz simiorg (hybryda psa, pawia i lwa). Zwierzęta te zdobią stroje postaci ukazanych na późnosasanidzkim reliefie z Taq-e Bustan. W sasanidzkiej Persji szyje i nogi zwierząt dekorowano niekiedy powiewającymi wstęgami, które znane są też jako ozdoby władców. Dla sztuki perskiej charakterystyczne są także sceny polowania na lwy czy przedstawienia jeźdźców w pozycji strzału partyjskiego. Oprócz postaci i zwierząt, ze sztuki irańskiej pochodzą medaliony otoczone motywem pereł. Czasem przedstawiano je rozłącznie, jednak najczęściej okręgi stykają się ze sobą $\mathrm{w}$ punktach kardynalnych. W miejscu styku medalionów przeważnie umieszczony jest kwadrat lub mniejszy medalion z sierpem księżyca. Nie wszyscy zgadzają się z irańskim pochodzeniem „perłowych medalionów”. Jak słusznie zauważył Michael W. Meister (1970: 256), okręgi otoczone rzędem mniejszych kół występują także 
na materiałach chińskich, gdzie zazwyczaj okalają rozetę (il. 6), czasem mityczne zwierzęta. Motyw ten pojawił się w czasach panowania dynastii Sui (581-618 r. n.e.). Należy jednak zaznaczyć, że na materiałach chińskich medaliony są znacznie mniejsze. Ponadto nie posiadają dodatkowych elementów w punktach kardynalnych. Tym samym autorka niniejszego artykułu przychyla się do tezy mówiącej o perskim pochodzeniu tzw. „perłowych medalionów” występujących na tkaninach będących przedmiotem tej pracy. Ze sztuki chińskiej pochodzi szereg innych ornamentów roślinnych i geometrycznych, a także antytetyczne ustawienie zwierząt (Compareti 2006). Pary mitycznych feniksów (chiń. fenghuang) lub smoków zdobiły chociażby adamaszki pochodzące $\mathrm{z}$ okresu panowania dynastii Han (206 r. p.n.e.-220 r. n.e.). Z jedwabiów chińskich znane jest również drzewo rozdzielające zwierzęta oraz podesty, na których stoją. Są to ornamenty w kształcie rozłożonych liści. Mateo Compareti (2006) uważa, że wywodzą się od sasanidzkich skrzydeł (prawdopodobnie autorowi chodziło o symboliczne przedstawienie Chwernach lub Ahuramazdy). Jednak ornament ten występuje na tradycyjnych chińskich tkaninach, co wskazuje na jego wschodnią proweniencję. Sir Aurel Stein nazwał go „zwiniętymi, szpiczastymi liśćmi ukazanymi z profilu" (Meister 1970: 260). Dla sztuki chińskiej charakterystyczne są także rozbudowane rozety składające się z czterech ornamentów florystycznych okalających kwiat lotosu otoczony okręgiem zbudowanym z mniejszych kół. Motyw ten pojawił się w okresie panowania dynastii Tang (618-907 r. n.e.) i był najczęściej umieszczany pomiędzy „perłowymi medalionami” (il. 4). Rozeta jest prawdopodobnie rozbudowaną formą kapryfoliów, które zdobiły przestrzeń pomiędzy wyżej wspomnianymi medalionami z czasów panowania dynastii Sui (il. 6) (Meister 1970: 265).

W miarę rozprzestrzeniania się wzoru ulegał on pewnym przemianom. „Perłowe medaliony” zastępowano czasami ornamentami roślinnymi i geometrycznymi. Popularne stało się przedstawianie jeleni (il. 2), które mimo że znane są ze sztuki sasanidzkiej (chociażby z reliefów przedstawiających królewskie polowanie na jelenie), jako ozdoba tkanin zostały wprowadzone najprawdopodobniej w Sogdianie. Jak słusznie zauważa Etsuko Kageyama (2006: 319-320), jeleń nie jest znany jako ozdoba strojów sasanidzkich, ale za to często występuje na metalowych naczyniach produkcji sogdyjskiej. Według Kazuko Yokohari (2006: 161) schematyczne przedstawienie powiewającej wstęgi (il. 4, 5) w postaci trójkątów, które często występuje na opisywanych tkaninach, również wywodzi się ze sztuki sogdyjskiej.

Ze względu na obecność elementów sogdyjskich, a także utożsamianie większości tkanin z badanym wzorem z tzw. jedwabiami zan- 
danijī, często przyjmuje się, że miejscem wykształcenia się owego synkretycznego stylu była Sogdiana. Szybkie rozprzestrzenienie się tkanin $\mathrm{i}$ w następstwie przejęcie wzoru przez ościenne imperia wynikałoby z prężnej działalności handlowej na Jedwabnym Szlaku, który od $\mathrm{V}$ do $\mathrm{X}$ w. n.e. bez wątpienia był zdominowany przez kupców sogdyjskich (Sims-Williams 1996: 45-67). Tkaniny należące do grupy zandaniji po raz pierwszy zostały wydzielone przez W. B. Henninga i D. C. Shepherd po odczytaniu w 1959 r. sogdyjskiej inskrypcji na jedwabnej tkaninie odkrytej w kościele w Huy (Belgia). Według tłumacza słowo zandanechi jest tożsame $\mathrm{z}$ nazwą zandanijji, znaną ze źródeł perskich i arabskich (za Marshak 2006: 49), która miała się wywodzić od nazwy osady Zandan ulokowanej w pobliżu Buchary. Tkaniny te odkrywane są zarówno w europejskich katedrach, buddyjskich klasztorach (np. w Dunhuang) oraz na cmentarzyskach znajdujących się na Jedwabnym Szlaku od Kaukazu po Tybet (np. Moszczevaja Balka, Turfan, Dulan) (Liu 2010: 81-82). Charakteryzują się krzykliwymi kolorami przędzy, sasanidzkimi motywami i podobną techniką wykonania (Watt 1997: 22). Jednak według Borisa I. Marshaka (2006) tekstylia zaliczane do tej grupy nie są bezpośrednio związane ze sztuką sogdyjską i były produkowane od drugiej połowy VIII w. do pierwszej połowy IX w. we wschodnich prowincjach kalifatu Abbasydów, a także w niezależnych rejonach wschodniej części Azji Środkowej.

Z całą pewnością Sogdiana słynęła z wyrobów tekstylnych, które zarówno pod względem technologicznym, jak i wzornictwa noszą wyraźne znamiona rzemiosła perskiego. Najwięcej informacji o tekstyliach z Sogdiany dostarczają malowidła ścienne zdobiące ściany kaplic oraz prywatnych rezydencji odkrytych w Pendżykencie, Afrasiabie (Samarkanda) oraz w Warachszy. Są to przedstawienia narracyjne, sceny bankietów, wizerunki bogów, a także dekoracje składające się z ornamentów geometrycznych i roślinnych. Motywy charakterystyczne dla sztuki sasanidzkiej pojawiają się na malowidłach datowanych dopiero na VII w. n.e. Na początku VIII w. n.e., kiedy Sogdiana dostała się pod zwierzchnictwo chińskiej dynastii Tang, zaczęto przedstawiać także tkaniny typowe dla warsztatów chińskich. Niektóre postacie ukazano w szatach uszytych z chińskich adamaszków, na krawędziach obszyte „sasanidzkimi” samitami (Azarpay 1981: Plate 29). Mimo współwystępowania tkanin „sasanidzkich” i „chińskich” na malowidłach z Sogdiany nie występują tkaniny, które łączyłyby oba style zdobnicze. Oznacza to, że najprawdopodobniej co najmniej do połowy VIII w. n.e. na terytorium Sogdiany nie tkano tekstyliów, które zaliczane są do grupy zandaniji. Należy zatem przyj- 
rzeć się bliżej tkactwu chińskiemu oraz warsztatom $\mathrm{w}$ oazach Wschodniego Turkiestanu.

W dziele Lidai minghua ji Zhang Yanyuan pisał, że we wczesnym okresie panowania dynastii Tang w cesarskich warsztatach w Syczuanie powstawały wysokiej jakości jedwabie (ruijin) ze wzorami przedstawiającymi antytetycznie ustawione zwierzęta, ptaki, a czasem postacie (Yokohari 2006: 166). Materiały te nie tylko wyglądały podobnie do swoich irańskich prototypów, ale także były wykonane tą samą techniką. Proporcje osnowy wiążącej w stosunku do osnowy figurowej zachowano podobne jak w przypadku tkanin zachodnich, a jedyna różnica technologiczna polegała na użyciu osnowy skręconej lewoskrętnie (S) (Yokohari 2006: 157). Przykłady takich tekstyliów odkryto w dwóch depozytach w Nara (il. 4). Do Japonii trafiły prawdopodobnie w 705 r. n.e. wraz z delegacją powracającą z dworu cesarzowej Wu Zetian (690-705 r. n.e.) (Yokohari 2006: 167).

Oprócz perskich motywów warsztaty chińskie przejęły także technikę tkacką. Materiały wykonane splotem wzorzystym wątkowym o wiązaniu skośnym zaczęły powstawać w Chinach na przełomie VII i VIII w. n.e. (Sheng 2006: 121). Wcześniej polichromiczne tkaniny luksusowe tkano splotem wzorzystym osnowowym o wiązaniu płóciennym. Technika ta polega na przeplataniu osnowy podstawowej i kolorowych nitek osnowy figurowej z nićmi wątku. W tym przypadku wzór był tworzony poprzez dobieranie nici osnowy. Ponadto tkaninę wiązano splotem płóciennym. Należy zaznaczyć, że zmiana w technologii zachodziła znacznie wolniej niż w zdobnictwie, mimo to wydaje się, że wszelkie innowacje techniczne i dekoracyjne mogły dokonać się na tym samym obszarze, najprawdopodobniej we Wschodnim Turkiestanie (w Kotlinie Tarymskiej i Turfańskiej). Jest to teren położony w dzisiejszej Ujgurskiej Republice Autonomicznej Xinjiang w Chinach. Od północy otoczony jest przez góry Tien Szan, natomiast od zachodu i południa przez Kunlun i Pamir. Wschodni Turkiestan prawie w całości pokrywa pustynia Takla Makan. Bardzo niekorzystne warunki klimatyczne sprawiają, że osadnictwo mogło rozwijać się jedynie $w$ pasie oaz umieszczonych pomiędzy górami a pustynią. Był to naturalny korytarz, który przemierzały karawany kupieckie. Oazy Kotliny Tarymskiej oraz Oaza Turfan były nie tylko punktem przystankowym w drodze z Bliskiego Wschodu do Chin, ale także miejscem zakładania faktorii kupieckich. Choć zachowały się liczne dokumenty, dosyć trudno odtworzyć dokładny obraz etniczny populacji Wschodniego Turkiestanu. W oazie Turfan, szczególnie istotnej ze względu na bardzo dużą liczbę zachowanych tkanin z mo- 
tywami sasanidzkimi i chińskimi, od podboju chińskiego w okresie panowania dynastii Han większą część mieszkańców stanowili Chińczycy. Wiadomo jednak, że nadal istniała autochtoniczna społeczność pochodzenia indoeuropejskiego, która zasiedlała oazę co najmniej od II tys. p.n.e. (Mallory 2000). Ponadto imiona wymieniane w odkrytych tekstach świadczą o obecności Sogdyjczyków (Hansen 2005: 283-310). Wieloetniczność oaz sprzyjała transkulturacji, czyli procesowi powstawania synkretycznej kultury, która zaczęła oddziaływać także na tzw. kultury dawców.

Hodowla jedwabnika w oazach Wschodniego Turkiestanu rozpoczęła się dopiero $\mathrm{w}$ połowie I tys. n.e. Wcześniej jedwabne nici oraz tkaniny sprowadzano $\mathrm{z}$ Chin, które za wszelką cenę próbowały utrzymać monopol na produkcję tego cennego surowca. Według legendy opisanej przez chińskiego mnicha Xuanzanga (Beal 1884: 318319), który na początku VII w. n.e. wędrując do Indii, przemierzył Kotlinę Kaszgarską, larwy jedwabnika oraz nasiona morwy zostały przemycone do oazy Chotan przez chińską księżniczkę. Wydarzenie to miało jakoby miejsce w 419 r. n.e. Podobna historia została zilustrowana na drewnianej plakietce odkrytej na początku XX w. w Dandan-oilik przez Sir Aurela Steina (1907: 300). Trudno ocenić, ile jest prawdy, a ile legendy $w$ historii przemytu jedwabiu, aczkolwiek faktem jest, że hodowla jedwabnika w oazie Chotan rozpoczęła się już w V w. n.e., a stamtąd dosyć szybko rozprzestrzeniła się na pobliskie oazy. Świadczą o tym nie tylko znaleziska archeologiczne, ale przede wszystkim dokumenty pisane, odkryte m.in. na stanowisku Turfan (Zhang Guang-da 1996: 282-297).

Do produkcji luksusowych, wzorzystych tkanin nie wystarczyli wyspecjalizowani tkacze ani posiadanie jedwabnych nici. Do utkania materiałów z powtarzającymi się cyklicznie wyrafinowanymi wzorami było potrzebne krosno z podciąganymi licami. Datowane na połowę VII w. n.e. dokumenty pochodzące z Astany i Choczo (Oaza Turfan) zawierają informacje o sogdyjskich i chińskich rzemieślnikach pracujących w oazie (Sheng 2006: 119). Wśród wymienionych osób znajduje się dwóch cieśli pracujących w drewnie bambusowym. Byli to najprawdopodobniej konstruktorzy krosien $\mathrm{z}$ podciąganymi licami, które wykonywano $\mathrm{z}$ tego samego surowca także w Syczuanie, regionie słynącym z wyrobów jedwabnych (Sheng 2006: 119).

Na stanowiskach Astana i Choczo odkryto liczne fragmenty tkanin datowanych od połowy V w. n.e. do połowy VIII w. n.e. Są to zarówno materiały wełniane, jak i jedwabne. Niektóre z tkanin bez wątpienia pochodzą z Chin. Jedwabie z sasanidzkimi motywami można podzielić co najmniej na trzy grupy. Etsuko Kageyama (2006) uważa, że wysokiej jakości tkaniny, które pokryte są jedynie motywami zna- 
nymi ze sztuki sasanidzkiej, mogą być importami perskimi. Natomiast tkaniny gorszej jakości ozdobione tym samym repertuarem motywów, aczkolwiek wykonanych w bardziej schematyczny sposób, pochodzą z warsztatów sogdyjskich lub były produkowane lokalnie we Wschodnim Turkiestanie. Do trzeciej grupy należą tkaniny tzw. typu sogdyjsko-turfańskiego (Compareti 2006), czyli te, których dekoracja złożona jest z elementów charakterystycznych dla sztuki sasanidzkiej i chińskiej. Co ciekawe, są to najstarsze znane przykłady materiałów łączących oba style. Niełatwo udowodnić, że powstały $\mathrm{w}$ lokalnych warsztatach, jednakże, $\mathrm{z}$ powodu braku podobnych przedstawień na malowidłach sogdyjskich, nie ma wystarczających przesłanek, aby przypuszczać, że powstały na zachodzie. Nowy styl mógł narodzić się także w głębi terytorium chińskiego, ale wydaje się bardziej prawdopodobne, że do transformacji doszło na obszarze będącym pod silnym oddziaływaniem kultury zarówno chińskiej, jak i sogdyjskiej. Wieloetniczne oazy Wschodniego Turkiestanu były miejscem idealnym dla procesów kulturotwórczych. Według opinii Angeli Sheng (2006: 117) do zmian w technologii oraz w zdobnictwie doszło dzięki współpracy chińskich i sogdyjskich tkaczy zamieszkujących oazy Xinjiangu.

Najstarsze znaleziska $\mathrm{z}$ oazy Turfan świadczące o adaptowaniu zachodnich motywów pochodzą z drugiej poł. VI w. n.e. Są to nieliczne przykłady jedwabi wykonanych splotem wzorzystym osnowowym o wiązaniu płóciennym, a więc techniką właściwą tkaczom chińskim. Jedwabie są dekorowane wzorem umieszczonym $\mathrm{w}$ typowych sasanidzkich medalionach $\mathrm{z}$ motywem kwadratu w punktach kardynalnych (Yokohari 1991: 53). Z tego samego okresu pochodzą także dwa bardzo ciekawe materiały służące jako maski pośmiertne osób pochowanych w Astanie (il. 7). Jeden z kawałków został odkryty $\mathrm{w}$ grobie $\mathrm{nr}$ 18, datowanym na 589 r. n.e., natomiast drugi w grobie nr 168, który datuje się na 558 r. n.e. Tkaniny zdobią identyczne wzory składające się ze stojącego przed ołtarzem ognia mężczyzny, który prowadzi objuczonego wielbłąda. Całość sceny otoczona jest medalionem z drobnymi perłami. Pomiędzy postacią a wielbłądem są umieszczone chińskie znaki (hu-wang) oznaczające „Barbarzyńskiego Władcę" (Yokohari 1991: 52, Compareti 2006). Na tkaninie wykonanej splotem charakterystycznym dla warsztatów chińskich przedstawiono prawdopodobnie Sogdyjczyka.

Z VI w. n.e. pochodzą także dwa jedwabie stanowiące zapowiedź powstania nowej konwencji w zdobnictwie tkanin. Są to materiały utkane splotem wzorzystym osnowowym o wiązaniu płóciennym. 
Oba materiały zostały odkryte na stanowisku Astana. Pierwszy z nich pochodzi z jaskini 306, dla której terminus ante quem to rok 541. Jeden $\mathrm{z}$ rzędów ozdób składa się z motywów antytetycznie ustawionych feniksów znajdujących się nad ornamentem rozłożonych liści. Nad nimi przedstawiona jest para jeleni. Motywy rozdzielone są ornamentem kwiatu o ośmiu płatkach (Meister 1970: Fig. 19). Kolejna tkanina (il. 8) została odkryta w jaskini nr 303, dla której terminus ante quem to 551 r. n.e. Materiał jest ozdobiony powtarzającym się wzorem antytetycznie ustawionych feniksów, nad którymi znajdują się uskrzydlone konie oraz niedźwiedzie. Całość przedstawienia otoczona jest łańcuchem pereł o owalnym kształcie. Na jego styku umieszczono motyw ośmiopłatkowego kwiatu (Meister 1970: 260261). Ten ornament będzie bardzo często wykorzystywany do łączenia „perłowych medalionów” zdobiących turfańskie tkaniny z VII w. n.e. Jednym z przykładów jest fragment jedwabnego materiału z jaskini 302 (625 r. n.e.) o splocie wzorzystym osnowowym o wiązaniu płóciennym, na którym przedstawiono umieszczone we wspomnianych wyżej medalionach pary pegazów (Mester 1970: Fig. 22). W górnym rejestrze ustawione antytetycznie konie znajdują się nad podestem $\mathrm{w}$ kształcie rozłożonych liści. $\mathrm{W}$ dolnym rzędzie pegazy stoją przed schematycznie ukazanym drzewem. W wolnych przestrzeniach pomiędzy medalionami znajduje się motyw kapryfolium. Jest to najstarsza znana tkanina, która mimo braku wyraźnych wpływów sasanidzkich (jedynie „perłowy medalion”) jest ozdobiona w konwencji typowej dla tkanin będących przedmiotem niniejszej pracy.

Na cmentarzysku Astana odkryto jeszcze cztery jedwabie dekorowane bardzo podobnym wzorem. Pierwszy z nich, wykonany splotem wzorzystym wątkowym o wiązaniu płóciennym, nadal nie posiada dodatkowych elementów zapożyczonych ze sztuki sasanidzkiej (il. 9). Powiewające wstęgi zaczepione na szyjach i nogach pegazów występują na dwóch bardzo podobnych materiałach (il. 10,11) odkrytych w grobowcu nr 519, datowanym na 642 r. n.e., i nr 302, pochodzącym z roku 653. Konie, w przeciwieństwie do konwencji chińskiej, według której przedstawiano je w ruchu, zostały zobrazowane w statyczny sposób, charakterystyczny dla sztuki sasanidzkiej. Identyczny wzór zdobi także inną tkaninę (Meister 1970: Fig. 25) odkrytą w grobowcu 302. W odróżnieniu od wcześniejszych materiałów jest ona utkana splotem wzorzystym osnowowym o wiązaniu skośnym. Jest to technika uważana za przejściową pomiędzy splotem wzorzystym osnowowym o wiązaniu płóciennym a wzorzystym wątkowym o wiązaniu skośnym. Stosowano ją sporadycznie od czasów panowania dynastii Sui (Sheng 2006: 121). 
Identyczne fragmenty tkanin (Heller 1998: Fig. 17), wykonane splotem wzorzystym osnowowym o wiązaniu skośnym, odkryto w 1983 r. na stanowisku Reshui w chińskiej prowincji Dulan, która w przeszłości była częścią imperium tybetańskiego. Tkaniny znajdowały się w bogatych grobowcach kurhanowych datowanych na VIIIIX w. n.e. Wśród wyposażenia, oprócz wyrobów tybetańskich, znajdowały się także importowane naczynia sogdyjskie (Heller 1998: 86). Dulan leży na szlaku łączącym Xinjiang z Tybetem, dlatego też obecność importów nie jest zadziwiająca. Zastanawiająca jest jednak proweniencja jedwabnych tkanin. Część z nich była bez wątpienia sprowadzana $\mathrm{z}$ Chin. Tym samym tkaniny łączące styl sasanidzki i chiński mogły powstać w warsztatach syczuańskich. Bardziej prawdopodobne jest jednak, że do Dulan przybyły z Xinjiangu wraz z importami sogdyjskimi. Część eksportowanych materiałów została w imperium tybetańskim, natomiast reszta mogła trafić do Syczuanu, gdzie w czasach panowania dynastii Tang zaczęto naśladować nowatorski styl, uzupełniając go o nowe elementy, nierzadko zaczerpnięte $\mathrm{z}$ oryginalnych tkanin sasanidzkich. Trafiały one na dwór chiński nie tylko za pośrednictwem sogdyjskim, ale także na drodze oficjalnej wymiany handlowej pomiędzy imperiami, która została wznowiona w czasach panowania dynastii Sui (Pulleyblank 1991). Od VIII w. n.e. tkaniny zdobione synkretycznym sasanidzko-chińskim wzorem powstawały także $w$ samej Sogdianie, jak i w innych rejonach nowo powstałego imperium arabskiego.

W świetle dotychczasowych odkryć wydaje się, że do powstania synkretycznego wzoru, który jest przedmiotem niniejszej pracy, doszło w oazie Turfan lub w pobliskich oazach Kotliny Tarymskiej. Część tkanin pochodząca z Xinjiangu może być dziełem obcych rzemieślników zamieszkujących faktorie handlowe. Należy także podkreślić, że sasanidzkie motywy zostały rozpropagowane głównie przez kupców sogdyjskich, którzy mieli niewątpliwy wpływ na zmiany kulturowe, do jakich dochodziło na obszarze Jedwabnego Szlaku. Wymiana handlowa przyczyniła się nie tylko do wzrostu zapotrzebowania na egzotyczne towary, ale także doprowadziła do zaadaptowania obcych elementów kultury oraz zmian technologicznych. Fenomen ten widoczny jest nie tylko w przemyśle tekstylnym, ale także $\mathrm{w}$ wielu innych gałęziach rzemiosła i sztuki. Wraz z transferem kultury materialnej dochodziło do przejmowania myśli, idei i religii. Autorka ma nadzieję, że kolejne odkrycia archeologiczne, a także szczegółowa analiza tkanin pod względem technologicznym (analiza splotów, barwników itp.) dostarczą informacji, mogących nie tylko rzucić no- 
we światło na pochodzenie opisywanego wzoru, ale także przyczynić się do wysnucia szerszych wniosków na temat interakcji kulturowych na terenach, przez które przebiegał Jedwabny Szlak.

\section{Bibliografia}

Azarpay, Guitty (red.). 1981. Sogdian Painting: The Pictoral Epic in Oriental Art. Berkeley, Los Angeles, London: University of California Press.

Beal, Samuel. 1884. Si-Yu-Ki: Buddhist Record of the Western World. Translated from the Chinese of Xuanzang. Vol. II. London: Trübner \& Co., Ludgate Hill.

Compareti, Mateo. 2006. The Role of the Sogdian Colonies in the Diffusion of the Pearl Roundels Pattern: Mateo Compareti, Paola Raffetta, Gianroberto Scarcia (red.). Ërān ud Anērān: Studies Presented to Boris Maršak on Occasion of His 70th Birthday. Venezia: Venezia Cafoscarina, 149-174.

Feltham, Heleanor. 2010. Lions, Silks and Silver: The Influence of Sasanian Persia, Sino-Platonic Papers 206, 1-51.

Ghirshman, Roman. 1962. Iran, Parthians and Sasanians. London: Thames and Hudson.

Hansen, Valerie. 2005. The Impact of the Silk Road Trade on a Local Community: The Turfan Oasis, A.D. 500-800: Étienne De La Vaissière, Eric Trombert (red.). Les Sogdiens en Chine, Paris: Ecole Francaise Extreme Orient, 283-310.

Heller, Ammy. 1998. Some Preliminary Remarks on the Excavations at Dulan, Orientations 29, 84-95.

Kageyama, Etsuko. 2006. Use and Production of Silks in Sogdiana: Mateo Compareti, Paola Raffetta, Gianroberto Scarcia (red.). Erān ud Anērān: Studies Presented to Boris Maršak on Occasion of His 70th Birthday. Venezia: Venezia Cafoscarina, 317-332.

Liu, Xinru. 2010. The Silk Road in World History. Oxford: Oxford University Press.

Mallory, J.P., V.H. Mair. 2000. The Tarim Mummies. Ancient China and the Mystery of the Earliest Peoples from the West. London: Thames and Hudson.

Marshak, Boris I. 2006. The So-Called Zandanijī Silk: Comparison with the Art of Sogdia: Regula Schorta (red.). Central Asian Textiles and their Contexts in the Early Middle Ages. Riggisberg: AbeggStiftung, 49-60.

Sheng, Angela. 2006. Textiles from Astana: Art, Technology, and Social Change: Regula Schorta (red.). Central Asian Textiles and 
their Contexts in the Early Middle Ages. Riggisberg: Abegg-Stiftung, 117-127.

Sims-Williams, Nicholas. 1996. The Sogdian Merchants in China and India: Alfredo Cadonna, Lionello Lanciotti (red.). Cina e Iran da Alessandro Magno alla dinastia Tang, Orientalia Venetiana. Florence: Olschki, 45-67.

Stein, Aurel. 1907. Ancient Khotan: Detailed Report of Archaeological Explorations in Chinese Turkestan. Vol. I. Oxford: Clarendon Press.

Watt, James C. Y., Anne E. Wardwell. 1997. When Silk Was Gold, Central Asian and Chinese Textiles. New York: Metropolitan Museum of Art.

Yokohari, Kazuko. 1991. An Essay on the Debut of the Chinese Samit Based on the Study of Astana Textiles, Bulletin of the Ancient Orient Museum Vol. XII, 41-101.

Yokohari, Kazuko. 2006. The Hōryū-ji Lion-hunting Silk and Related Silks: Regula Schorta (red.). Central Asian Textiles and their Contexts in the Early Middle Ages. Riggisberg: Abegg-Stiftung, 155173.

Zhang Guang-da. 1996. The City States of the Tarim Basin: Boris A. Litvinsky (red.). History of Civilisations of Central Asia, vol. III: The Cross-roads of Civilizations: A.D. 250 to 750. Paris: UNESCO, 237281.

\section{Źródła internetowe}

Pulleyblank, Edwin G. 1991. Chinese-Iranian Relations i. In Pre-Islamic Times: Encyclopcedia Iranica [edycja on-line], http://www.iranicaonline.org/articles/chinese-iranian-i, dostęp: 27.07.2013. 


\section{Ilustracje}

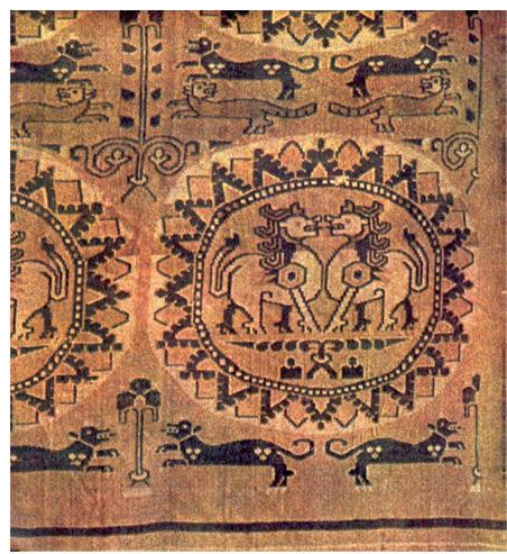

Il. 1 Tkanina odkryta wraz z relikwiami św. Pauli w katedrze Sens we Francji, VIII w. n.e. (Feltham 2010: Fig. 19)

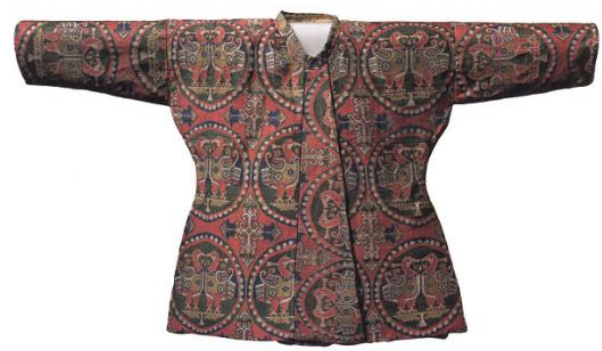

Il. 3 Płaszcz dziecięcy odkryty w Tybecie (Watt, Wardwell 1997: cat. no. 5)

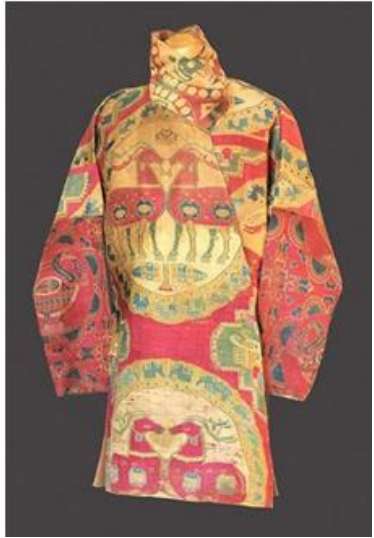

Il. 2 Jedwabny płaszcz odkryty w Tybecie, VIII w. n.e. (Feltham 2010: Fig. 11)

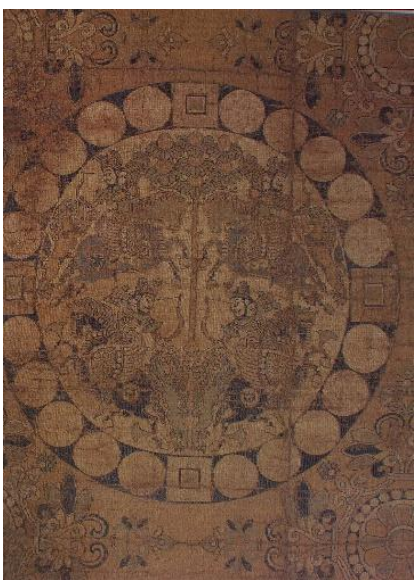

Il. 4 Fragment chińskiej tkaniny odkrytej w depozycie w Shosoin $\mathrm{w}$ Nara (Japonia) (Kuhn 2012: 1.29) 


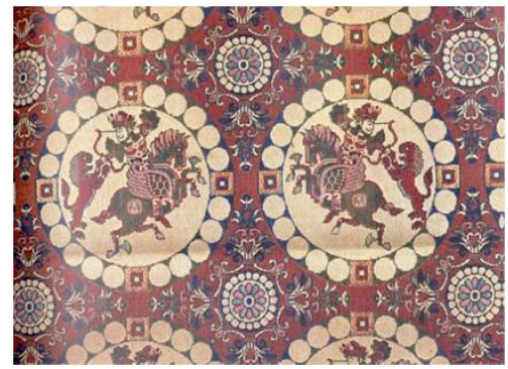

Il. 5 Tkanina pochodząca z warsztatów japońskich, VI-VII w. n.e., odkryta w depozycie Shoso-in w Nara (Japonia) (Feltham 2010: Fig. 9)

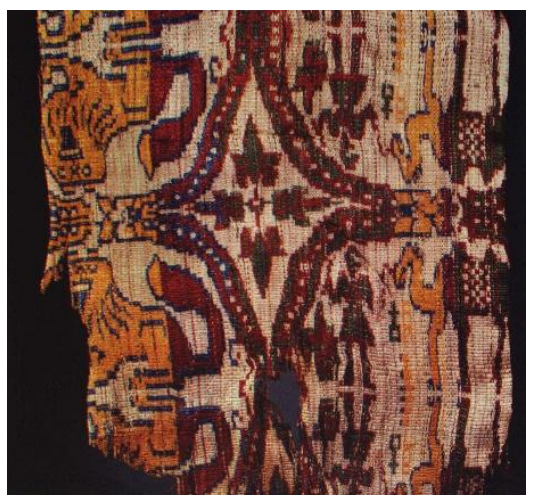

Il. 7 Jedwabna tkanina wykonana splotem wzorzystym osnowowym o wiązaniu płóciennym odkryta w grobie nr 169 w Astanie, 559 r. n.e. (Kuhn 2012: I. 17)

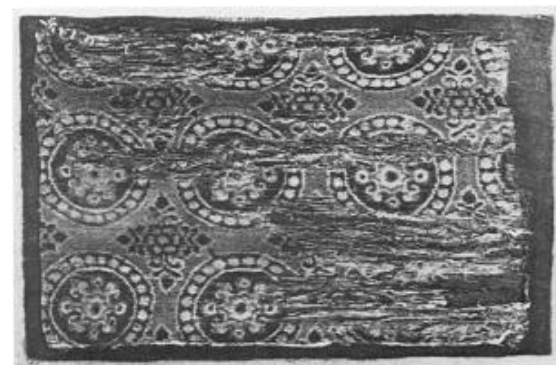

Il. 6 Tkanina wykonana splotem wzorzystym osnowowym o wiązaniu płóciennym, depozyt z Mount Mug (Meister 1970: Fig. 16)

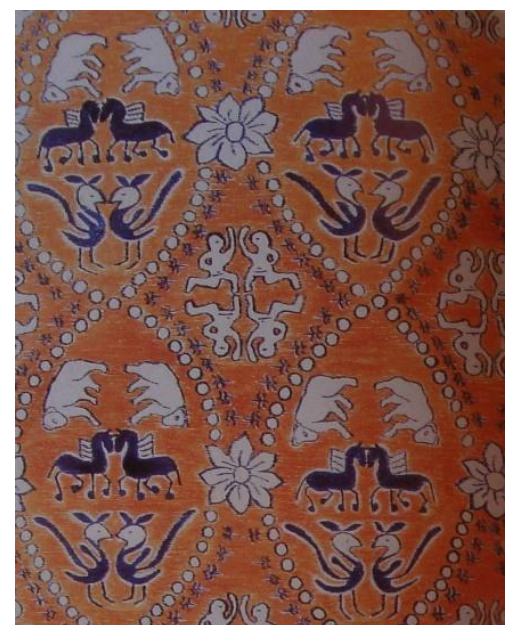

Il. 8 Tkanina wykonana splotem wzorzystym osnowowym o wiązaniu płóciennym, Astana (Kuhn 2012: 4.28) 


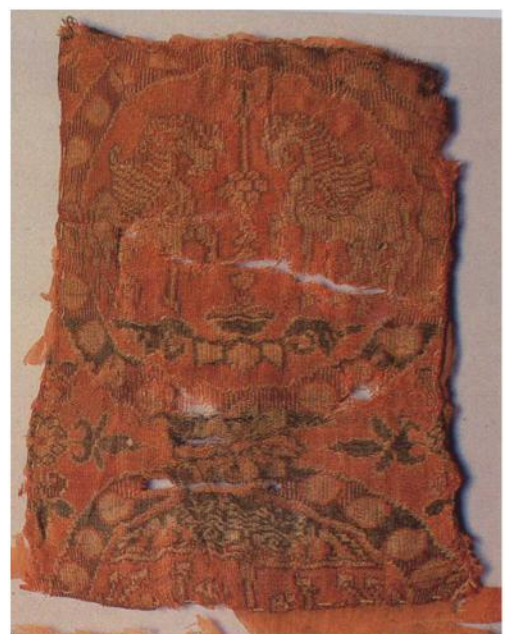

Il. 9 Tkanina wykonana splotem wzorzystym osnowowym o wiązaniu płóciennym, odkryta na stanowisku Astana, VII w. (Kuhn 2012: 1.26)

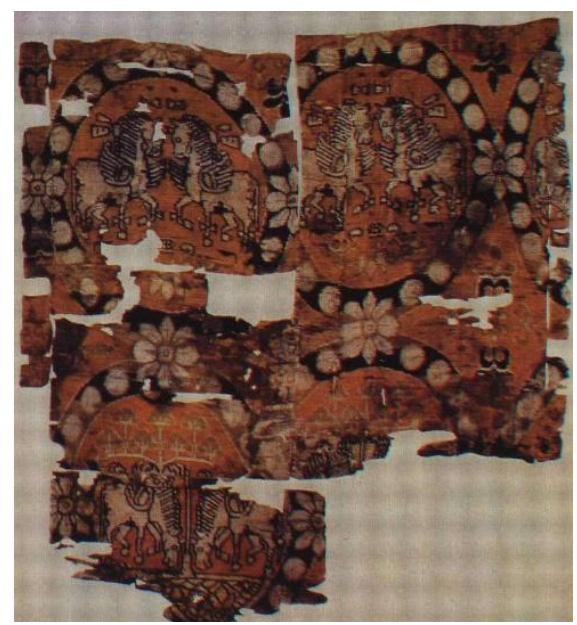

Il. 10 Tkanina wykonana splotem wzorzystym osnowowym o wiązaniu płóciennym, grób nr 519 w Astanie, 653 r. n.e. (Kuhn 2012: 1.24)

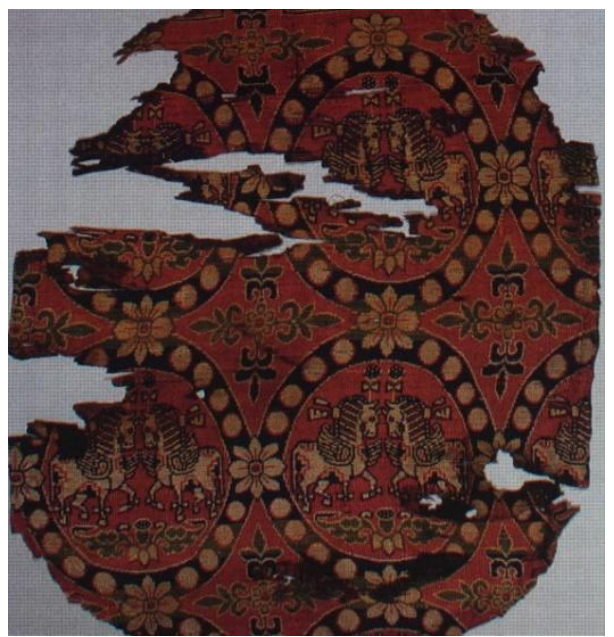

Il. 11 Tkanina wykonana splotem wzorzystym osnowowym o wiązaniu płóciennym, grób nr 302 w Astanie, 653 r. n.e. (Kuhn 2012: 1.25) 


\section{Abstract \\ Analysis of Emergence of Syncretic Designs in $6^{\text {th }}-7^{\text {th }}$ Century in Central Asia - Based on Textiles Discovered in Turfan Oasis}

In the $8^{\text {th }}$ century in Byzantine, Arabic and Chinese workshops weavers produced weft-faced compound twill silks (samits). These textiles were ornamented by confronted animals surrounded by pearls roundels. Usually, a rosette motive was placed between medallions. This design is a compilation of Sasanian (animals decorated with floating ribbons, pearl roundels) and Chinese patterns (symmetricalness, rosettes, 'scrolled leaves' motive). Its emergence took place in Central Asia. Some scholars think that it happened in Sogdiana, but the oldest samples of textiles made in the new tradition were found in Astana cemetery in Turfan Oasis (East Turkestan). Moreover, these textiles were warp-faced compound tabby - a weave technique characteristic of Chinese workshops. At first their composition was more Chinese than Sasanian, but successive Persian motives were more common. The most popular design was pearl roundels containing a confronted Pegasus standing on "a scrolled, pointed leaves in profile". There is a large possibility that textiles found in Astana were produced locally in East Turkestan, probably in Turfan Oasis, which is located on the north branch of Silk Road. It was inhabited by a local community, but also by Sogdian and Chinese merchants. This cooperation could have led to syncretism in art and technical changes.

Keywords: samit, textiles, Sasanian art, Central Asia, Turfan Oasis 